Review

\title{
Histoplasmosis in Liver Transplant Recipients: Case Reports and a Review of the Literature
}

Amy Spallone ${ }^{1,+, *}$, Udit Dhal ${ }^{1,{ }^{\dagger}}$, Laila Woc-Colburn ${ }^{1,2,3,{ }^{\dagger}}$, Marion Hemmersbach-Miller ${ }^{1,2,+, *}$

1. Department of Medicine, Section of Infectious Diseases, Baylor College of Medicine, Houston, TX 77030, USA; E-Mails: amy.spallone@bcm.edu; Udit.Dhal@bcm.edu; woccolbu@bcm.edu; Marion.Hemmersbach-Miller@bcm.edu

2. Department of Medicine, Section of Infectious Diseases, Baylor St. Luke's Medical Center, Houston, TX 77030, USA

3. National School of Tropical Medicine, Baylor College of Medicine, Houston, TX 77030, USA

+ These authors contributed equally to this work.

* Correspondences: Amy Spallone, Marion Hemmersbach-Miller; E-Mail: amy.spallone@bcm.edu; Marion.Hemmersbach-Miller@bcm.edu

Academic Editor: Yasuhiko Sugawara

Special Issue: Infections in Liver Transplantation

OBM Transplantation

2020, volume 4, issue 1

doi:10.21926/obm.transplant.2001103
Received: October 21, 2019

Accepted: February 26, 2020

Published: February 28, 2020

\begin{abstract}
We report two cases of histoplasmosis in orthotopic liver transplant (OLT) recipients to illustrate the variable presentations, complications encountered during treatment, the spectrum of diagnostic modalities, and case outcomes. Case 1 describes the insidious presentation of presumed gastrointestinal histoplasmosis 12 years after OLT, which was defined by months of intermittent diarrhea and focal colonic disease on colonoscopy. A diagnosis of Histoplasma capsulatum was ultimately made by broad range PCR performed on colonic tissue. Due to the patient's inability to tolerate itraconazole, treatment consisted of two weeks of liposomal amphotericin B with resolution of colonic ulcers on follow-up colonoscopy. Case 2 illustrates a case of severe pulmonary histoplasmosis with
\end{abstract}

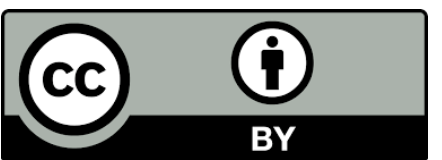

(C) 2020 by the author. This is an open access article distributed under the conditions of the Creative Commons by Attribution License, which permits unrestricted use, distribution, and reproduction in any medium or format, provided the original work is correctly cited. 
dissemination in an OLT recipient one year after transplantation. Treatment was complicated by the development of acute respiratory distress syndrome requiring mechanical ventilation and hemodynamic shock requiring extracorporeal membrane oxygenation therapy. A review of the literature on histoplasmosis in OLT recipients accompanies our cases and emphasizes the epidemiology, clinical manifestations, diagnosis, treatment, and prevention.

\section{Keywords}

Histoplasmosis; liver; transplant

\section{Introduction}

The geographic distribution of Histoplasma, a thermally dimorphic fungus found in soil, is dynamic and is thought to have a worldwide distribution [1]. Although the exact prevalence is not known, several studies have highlighted Brazil, Thailand, China, India, French Guiana, Africa, and Australia as countries of high endemicity [2-7]. Within the United States, the Ohio, Mississippi, and St. Lawrence River valleys represent the geographical niches with the highest endemicity of Histoplasma; however, outbreaks in states outside of these river valleys do occur $[6,8]$. Infection develops primarily through inhalation of infectious microconidia (Figure 1) [1, 3-5]. Alveolar macrophages then phagocytize the spores, allowing intracytoplasmic yeast forms to be seen on direct microscopy of Giemsa-stained macrophages (Figure 2). Donor-derived Histoplasma is a unique mode of infection that must be considered in transplant recipients $[1,9]$. Disease severity is dependent on several factors, including the load of inhaled conidia and the host's cellular immune response [1, 9]. Hematogenous dissemination of Histoplasma occurs in most patients after acute infection but rarely manifests as disseminated infection due to the development of cell-mediated immunity [10]. In a healthy host, sensitized T-cells alert macrophages to kill the intracellular organism. In the immunosuppressed host, Histoplasma remains viable in macrophages leading to progressive disseminated histoplasmosis that is fatal if left untreated [10]. Even in immunocompetent hosts, Histoplasma may not always be eradicated by cell-mediated immune response, but instead be contained, leading to potential reactivation at a later time if there is a decline in cellular immunity, such as after orthotopic liver transplantation (OLT) $[4,9]$. In this article, we describe two unique presentations of Histoplasma capsulatum infection occurring in OLT recipients, and we provide a review of the literature from 1996 through July 2019. 


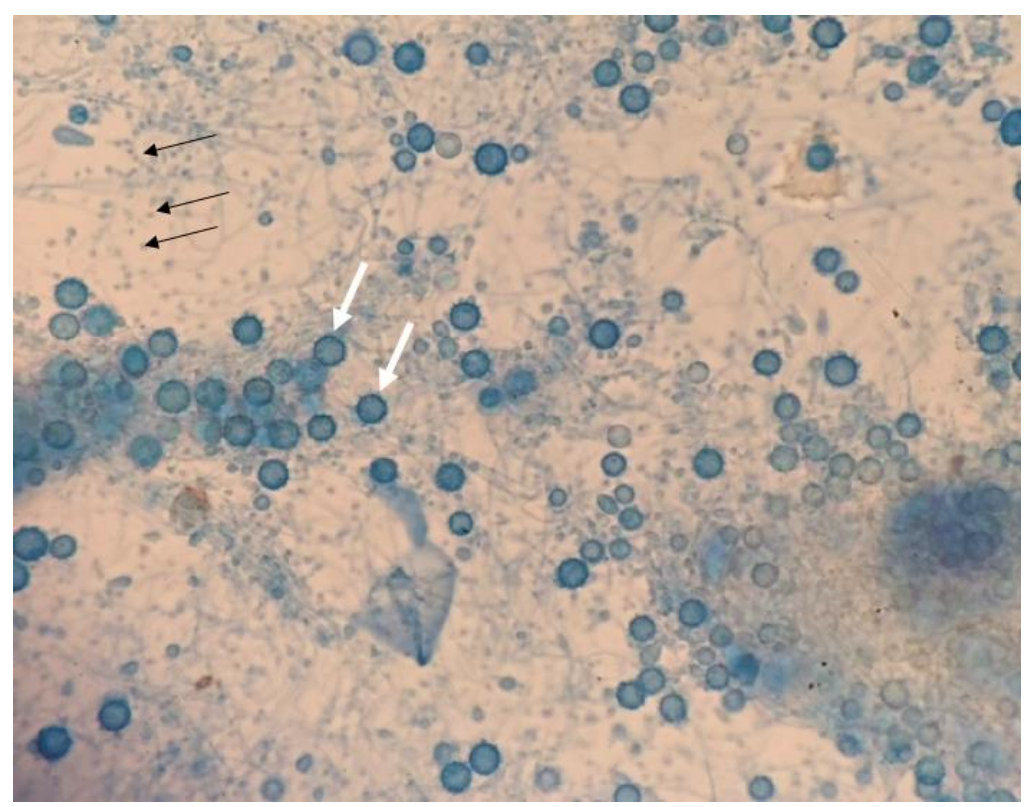

Figure 1 Present on hyaline and septate hyphae are abundant tuberculate, thickwalled macroconidia (white arrows) and numerous smooth-walled microconidia (black arrows) (Lactophenol cotton blue stain, magnification 40x). Figure courtesy of Dr. Todd M. Lasco, Microbiology Laboratory at Baylor St. Luke's Medical Center, Houston, TX 77030, USA.

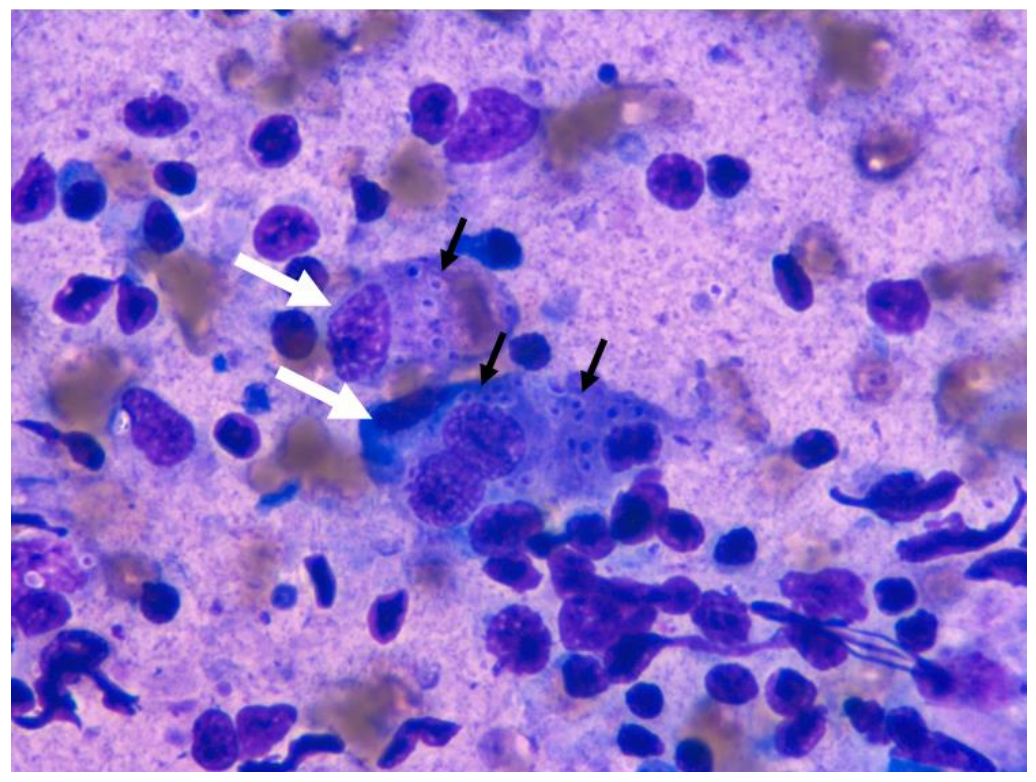

Figure 2 Fine needle aspiration smear showing intracellular yeast forms (black arrows) of Histoplasma within macrophages (white arrows) (Giemsa stain, magnification 1000x). Figure courtesy of Dr. Laila Woc-Colburn.

\section{Cases}

Per Baylor College of Medicine policies, case reports or case series describing interesting observations on three or fewer patients do not meet the definition of research. This submission is 
a case report. This submission is not considered research under 45 CFR 46.102(d). Therefore, this manuscript was exempt from IRB review and approval.

\subsection{Case 1}

A 51-year-old Caucasian female from Houston, Texas with a past medical history of chronic kidney disease and autoimmune hepatitis status post OLT 12 years prior presented with intermittent diarrhea of several months' duration. Her immunosuppressive regimen included: mycophenolate mofetil (MMF) and sirolimus. She underwent colonoscopy, which revealed an ulcerated, friable mass suspicious for malignancy in the ascending colon. On histopathology, necrotizing granulomatous inflammation was seen, and special stains for fungal organisms, acidfast bacilli (AFB), and immunohistochemical markers for cytomegalovirus, human herpesvirus 1 and 2 were negative. Colonic tissue microbiology studies were negative for organisms by Gram's stain and cultures for AFB, fungal organisms, and routine bacterial culture. Fungal serum studies for blastomycosis, coccidioidomycosis, and histoplasmosis were negative. Colonic tissue was sent for broad range $16 \mathrm{~S}$ ribosomal ribonucleic acid gene sequencing (University of Washington, Seattle, Washington), which was positive for Histoplasma capsulatum. Given the clinical presentation, necrotizing granulomas on histopathology, and Histoplasma detected in tissue by broad range PCR, a presumptive diagnosis of colonic histoplasmosis was made. The patient was started on itraconazole, but due to intolerability to the medication, treatment was switched to daily infusions of liposomal amphotericin B (LAmB) at $3 \mathrm{mg} / \mathrm{kg} / \mathrm{day}$ for two weeks. Her diarrhea resolved, and a repeat colonoscopy was performed one month after the completion of therapy showing normal mucosa throughout the entire colon. Histopathology from colonic mucosal biopsies revealed no significant diagnostic abnormalities. No further antifungal therapy was given due to patient preference, history of intolerance to itraconazole, chronic renal disease, clinically localized histoplasmosis without evidence of dissemination, and demonstration of resolved colonic lesions on colonoscopy. She maintains close medical follow up and has had no evidence of recurrence.

\subsection{Case 2}

A 34-year-old Hispanic male was admitted for worsening pancytopenia of a two-week duration. His past medical history was significant for end-stage liver disease secondary to alcoholic cirrhosis status post OLT one year prior. He lived in Houston, TX and recently started mowing the lawn and landscaping. Two weeks prior to the current hospitalization, he was admitted for fevers without associated symptoms and underwent an extensive infectious disease workup that only revealed Rhinovirus on a respiratory viral panel. He received supportive care at the time. Upon readmission, he revealed that he had been having persistent, daily fevers, and dry cough since discharge. His immunosuppressant regimen included the following: prednisone and tacrolimus. MMF had been stopped a few days prior to admission due to worsening cytopenia. His laboratory

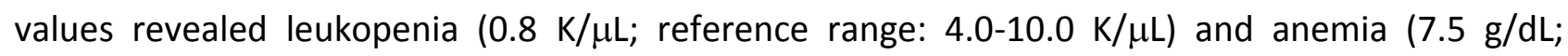
reference range: $13.0-16.8 \mathrm{~g} / \mathrm{dL})$. Chest computed tomography revealed diffuse reticulonodular markings and multifocal ground-glass opacities throughout the pulmonary parenchyma. The patient underwent bronchoscopy with lavage, which showed numerous predominantly intracellular yeast forms, suggestive of Histoplasma sp. Lavage fungal culture was positive for Histoplasma capsulatum, which was confirmed by deoxyribonucleic acid (DNA) probe. Urine 
Histoplasma Antigen was $>25.0 \mathrm{ng} / \mathrm{mL}$ (reference range: $<0.5 \mathrm{ng} / \mathrm{mL}$ ). Following a diagnosis of disseminated histoplasmosis, he was started on LAmB. Fevers and leukopenia resolved on LAmB; however, his hospital course was complicated by the development of acute respiratory distress syndrome (ARDS) requiring mechanical ventilation, hemodynamic shock requiring extracorporeal membrane oxygenation therapy and adjunctive corticosteroids, and acute kidney injury. His antifungal regimen consisted of 11 days of LAmB $3 \mathrm{mg} / \mathrm{kg} /$ day, followed by itraconazole $200 \mathrm{mg}$ twice daily for a planned twelve months of treatment. He retained his graft and slowly improved.

\section{Epidemiology}

Histoplasmosis has an extensive range in North America, extending from Canada into South America [1]. It is the most common endemic mycosis in the United States (U.S.) with substantial population exposure, by evidence of skin testing, dating back to the mid-twentieth century $[1,8]$. Even within the U.S., disease surveillance data has identified a growing number of cases in states not previously thought to be endemic, such as Michigan, New York, and Texas, among others $[1,8]$ Experts postulate that this expanding endemicity could be due to multiple factors, including a growing population of vulnerable, immunosuppressed hosts [1, 8]. A product of mitigated immune-mediated rejection, OLT patients are at higher risk of severe infection with Histoplasma due to impaired cellular immunity. Surveillance studies estimate that the incidence of histoplasmosis in transplant recipients in endemic areas is $<1 \%[1,4,5,11,12]$. The true incidence may be higher due to a lack of available laboratory support for surveillance and testing in some areas. On review of the literature, we identified twelve comprehensive case reports, spanning several countries, describing histoplasmosis infection in OLT recipients in the past two decades (Table 1).

\section{Modes of Acquisition}

Histoplasma infection in transplant recipients living in endemic areas is thought to occur primarily through inhalation of spores from exposure to disrupted soil [13]. However, reactivation of infection in the setting of immune suppression after transplantation or rejection can occur, even in nonendemic regions [1, 13]. Sylvestre et al. published a collection of images that showcased histopathology from a patient who had presumptive latent histoplasmosis then received an OLT. Fungal organisms were then seen on core-needle biopsy of the graft nine days after transplantation, prompting treatment [14]. Donor-derived infection is rare and estimated to occur in 1:10,000 transplants $[1,2,13,15,16]$. Our review of the literature found two case reports that featured presumed donor-derived histoplasmosis after liver transplantation (Table 1). Niyazi et al. described a 61-year-old male who received an OLT from a donor that was observed to have granulomatous inflammation of the spleen at autopsy [17]. The OLT recipient was placed on itraconazole for prophylaxis but developed severe infection five months post-transplant after discontinuing his antifungal medication. Botterel et al. describe a fatal case of disseminated histoplasmosis occurring seven months after OLT in a patient in France [2]. The recipient had no known travel to an endemic area; however, the donor lived in French Guiana for several years, suggesting Histoplasma was present in the liver at the time of transplantation. 
Table 1 Summary of case reports of Histoplasmosis in liver transplant recipients.

\begin{tabular}{|c|c|c|c|c|c|c|c|c|}
\hline References & $\begin{array}{l}\text { Age } \\
\text { (yrs) }\end{array}$ & $\begin{array}{l}\text { Presenting } \\
\text { signs/symptoms }\end{array}$ & $\begin{array}{l}\text { Onset post- } \\
\text { transplant } \\
\text { (mo.) }\end{array}$ & $\begin{array}{l}\text { Organ(s) } \\
\text { involved }\end{array}$ & Treatment \pm & $\begin{array}{l}\text { Method of } \\
\text { diagnosis }\end{array}$ & $\begin{array}{l}\text { Geographic } \\
\text { location } ¥\end{array}$ & $\begin{array}{l}\text { Immunosuppressive } \\
\text { Treatments ף }\end{array}$ \\
\hline 1. Case 1 & 51 & Diarrhea & 132 & $\begin{array}{l}\text { Gl tract } \\
\text { (colon) }\end{array}$ & $\begin{array}{l}\text { Itraconazole }, \\
\text { LAmB } 3 \\
\mathrm{mg} / \mathrm{kg} / \text { day for } 2 \\
\text { wks }\end{array}$ & $\begin{array}{l}\text { + Tissue PCR } \\
\text { (- Serum } \\
\text { Histoplasma Ab) }\end{array}$ & $\begin{array}{l}\text { Texas, } \\
\text { U.S.A. }\end{array}$ & MMF, sirolimus \\
\hline 2. Case 2 & 34 & $\begin{array}{l}\text { Fever, } \\
\text { pancytopenia, } \\
\text { cough }\end{array}$ & 12 & $\begin{array}{l}\text { Lungs, bone } \\
\text { marrow }\end{array}$ & $\begin{array}{l}\text { LAmB } 3 \\
\mathrm{mg} / \mathrm{kg} / \text { day for } \\
11 \text { days, } \\
\text { itraconazole } 200 \\
\mathrm{mg} \text { twice daily } \\
\text { for } 12 \text { mo. }\end{array}$ & $\begin{array}{l}\text { + BAL culture } \\
+ \text { Urine } \\
\text { Histoplasma Ag }\end{array}$ & $\begin{array}{l}\text { Texas, } \\
\text { U.S.A. }\end{array}$ & $\begin{array}{l}\text { Prednisone, } \\
\text { tacrolimus, MMF }\end{array}$ \\
\hline $\begin{array}{l}\text { 3. Nakamura, GP, } \\
\text { et al., Autops } \\
\text { Case Rep } 2019 \text { [3] }\end{array}$ & 36 & $\begin{array}{l}\text { Fever, diarrhea, } \\
\text { rash and oral } \\
\text { lesions }\end{array}$ & 96 & $\begin{array}{l}\text { Gl tract } \\
\text { (oral, } \\
\text { intestinal, } \\
\text { rectal) }\end{array}$ & $\begin{array}{l}\text { Itraconazole } 300 \\
\text { mg/day }\end{array}$ & + Histopathology & Brazil & $\begin{array}{l}\text { Prednisone } 5 \\
\text { mg/day, } \\
\text { MMF } 360 \text { mg }\end{array}$ \\
\hline $\begin{array}{l}\text { 4. Gomez- } \\
\text { Santana, LV, et } \\
\text { al. Actas } \\
\text { Dermosifiliogr } \\
2018 \text { (case 3) [18] }\end{array}$ & $75 \bullet$ & $\begin{array}{l}\text { Fever, skin } \\
\text { lesions }\end{array}$ & N/A & Skin & $\begin{array}{l}\text { LAmB } 5 \\
\mathrm{mg} / \mathrm{kg} / \text { day }\end{array}$ & $\begin{array}{l}\text { + Skin tissue } \\
\text { culture }\end{array}$ & Argentina & $\begin{array}{l}\text { Methylprednisone } 4 \\
\text { mg/day, tacrolimus } 3 \\
\text { mg twice daily, } \\
\text { MMF } 360 \text { mg twice } \\
\text { daily }\end{array}$ \\
\hline $\begin{array}{l}\text { 5. Agrawal, N, et } \\
\text { al. World J } \\
\text { Gastroenterol }\end{array}$ & $74 \bullet$ & $\begin{array}{l}\text { Diarrhea, } \\
\text { abdominal pain, } \\
\text { weight loss }\end{array}$ & 180 & $\begin{array}{l}\text { GI tract } \\
\text { (ileo-colonic) }\end{array}$ & N/A & + Histopathology & $\begin{array}{l}\text { United } \\
\text { Kingdom }\end{array}$ & $\begin{array}{l}\text { MMF 1g twice daily, } \\
\text { tacrolimus } 1 \mathrm{mg} \\
\text { twice daily, }\end{array}$ \\
\hline
\end{tabular}




\begin{tabular}{|c|c|c|c|c|c|c|c|c|}
\hline $2017[4]$ & & & & & & & & prednisone $5 \mathrm{mg} / \mathrm{day}$ \\
\hline $\begin{array}{l}\text { 6. Washburn, L, } \\
\text { et al. JSCR } 2017 \\
\text { [19] }\end{array}$ & 32 & $\begin{array}{l}\text { Body aches, } \\
\text { fever, } \\
\text { congestion, } \\
\text { dysuria, } \\
\text { transaminitis }\end{array}$ & 132 & Liver & $\begin{array}{l}\text { LAmB for } 11 \\
\text { days, } \\
\text { itraconazole for } \\
1 \mathrm{yr}\end{array}$ & $\begin{array}{l}\text { + Histopathology } \\
\text { + Urine } \\
\text { Histoplasma Ag }\end{array}$ & $\begin{array}{l}\text { Texas, } \\
\text { U.S.A. }\end{array}$ & MMF, tacrolimus \\
\hline $\begin{array}{l}\text { 7. Niyazi, F, et al. } \\
\text { Am J } \\
\text { Gastroenterol } \\
2015+\text { [17] }\end{array}$ & 61 & $\begin{array}{l}\text { Fever, } \\
\text { pancytopenia, } \\
\text { abdominal pain }\end{array}$ & 5 & Liver* & Itraconazole & $\begin{array}{l}\text { + Histopathology } \\
\text { + Urine } \\
\text { Histoplasma Ag }\end{array}$ & $\begin{array}{l}\text { Michigan, } \\
\text { U.S.A. }\end{array}$ & $\begin{array}{l}\text { Prednisone, } \\
\text { tacrolimus, MMF }\end{array}$ \\
\hline $\begin{array}{l}\text { 8. Wiederkehr, J, } \\
\text { et al. } \\
\text { Transplantation } \\
2014+[20]\end{array}$ & 18 & $\begin{array}{l}\text { Tonsillitis, oral } \\
\text { ulcers, fever, } \\
\text { weight loss }\end{array}$ & 9 & $\begin{array}{l}\text { Inferior vena } \\
\text { cava, liver, } \\
\text { spleen, GI } \\
\text { tract }\end{array}$ & $\begin{array}{l}\text { LAmB, } \\
\text { itraconazole }\end{array}$ & + Histopathology & Brazil & Tacrolimus, MMF \\
\hline $\begin{array}{l}\text { 9. Colaiacovo, } R \text {, } \\
\text { et al. Endoscopy } \\
2011+[21]\end{array}$ & 68 & Abdominal pain & 12 & $\begin{array}{l}\text { Gl tract } \\
\text { (stomach, } \\
\text { duodenum, } \\
\text { colon) }\end{array}$ & Itraconazole & + Histopathology & Brazil & $\mathrm{N} / \mathrm{A}$ \\
\hline $\begin{array}{l}\text { 10. Leite, CAC, et } \\
\text { al. Liver Transpl } \\
\text { 2009t [22] }\end{array}$ & 15 & Knee pain & 9 & $\begin{array}{l}\text { Left knee } \\
\text { synovium }\end{array}$ & Itraconazole & $\begin{array}{l}\text { + Synovial fluid } \\
\text { culture }\end{array}$ & Brazil & $\begin{array}{l}\text { Tacrolimus, } \\
\text { prednisone }\end{array}$ \\
\hline $\begin{array}{l}\text { 11. Oh, YS, et al. } \\
\text { Liver Transpl } \\
2006[23]\end{array}$ & 61 & Diarrhea & $N / A$ & $\begin{array}{l}\text { Gl tract } \\
\text { (colon), } \\
\text { pleural fluid }\end{array}$ & $\begin{array}{l}\text { LAmB } 100 \\
\text { mg/day for } 50 \\
\text { doses, } \\
\text { itraconazole } 200 \\
\text { mg twice dailya }\end{array}$ & $\begin{array}{l}\text { + Histopathology } \\
\text { + Urine } \\
\text { Histoplasma Ag } \\
\text { (- Serum } \\
\text { Histoplasma Ab) }\end{array}$ & $\begin{array}{l}\text { Missouri, } \\
\text { U.S.A. }\end{array}$ & $\begin{array}{l}\text { MMF } 1 \mathrm{~g} \text { twice daily, } \\
\text { tacrolimus } 2 \mathrm{mg} / \mathrm{day} \text {, } \\
\text { prednisone } 5 \mathrm{mg} / \mathrm{day}\end{array}$ \\
\hline $\begin{array}{l}\text { 12. Botterel, F, et } \\
\text { al. Eur J Clin }\end{array}$ & $46 \bullet$ & $\begin{array}{l}\text { Acute respiratory } \\
\text { failure, shock, }\end{array}$ & 7 & $\begin{array}{l}\text { Lungs, Gl } \\
\text { tract, spleen, }\end{array}$ & $A m B, L A m B$ & $\begin{array}{l}\text { + BAL cytology } \\
\text { + Tissue culture }\end{array}$ & France & $\begin{array}{l}\text { Tacrolimus, } \\
\text { azathioprine, }\end{array}$ \\
\hline
\end{tabular}




\begin{tabular}{|c|c|c|c|c|c|c|c|c|}
\hline $\begin{array}{l}\text { Microbiol Infect } \\
\text { Dis } 1999 \text { [2] }\end{array}$ & & jaundice & & $\begin{array}{l}\text { adrenal } \\
\text { glands, } \\
\text { lymph } \\
\text { nodes* }\end{array}$ & & & & $\begin{array}{l}\text { prednisone to } \\
\text { methylprednisolone, } \\
\text { muromonab-CD3 }\end{array}$ \\
\hline $\begin{array}{l}\text { 13. Vinayek, } R \text {, et } \\
\text { al. Clin } \\
\text { Transplant } 1998 \\
\text { [24] }\end{array}$ & 42 & $\begin{array}{l}\text { Pancytopenia, } \\
\text { transaminitis, } \\
\text { myalgia, fever, } \\
\text { nausea, vomiting }\end{array}$ & 6 & $\begin{array}{l}\text { Skin, liver, } \\
\text { bone } \\
\text { marrow, GI } \\
\text { tract } \\
\text { (prepyloric), } \\
\text { blood, lungs }\end{array}$ & $\begin{array}{l}\text { AmB } 8.5 g \text { total } \\
\text { dose, ABLC } 35 \\
\text { mg/day for } 2 \\
\text { wks then } \\
50 \mathrm{mg} / \text { twice } \\
\text { weekly for } 6 \\
\text { mo., } \\
\text { itraconazole } \\
200 \mathrm{mg} \text { twice } \\
\text { daily } \diamond\end{array}$ & $\begin{array}{l}\text { + Histopathology } \\
\text { + Bone marrow } \\
\text { culture } \\
\text { + Blood culture } \\
\text { + Urine } \\
\text { Histoplasma Ag }\end{array}$ & $\begin{array}{l}\text { West } \\
\text { Virginia, } \\
\text { U.S.A. }\end{array}$ & $\begin{array}{l}\text { Prednisone } 5 \\
\text { mg/day, } \\
\text { tacrolimus } 3 \text { mg/day, } \\
\text { MMF } 500 \text { mg twice } \\
\text { daily }\end{array}$ \\
\hline $\begin{array}{l}\text { 14. Shallot, J, et } \\
\text { al. Liver Transpl } \\
\text { Surg } 1997 \text { [25] }\end{array}$ & 44 & $\begin{array}{l}\text { Respiratory } \\
\text { symptoms, fever }\end{array}$ & 6 & $\begin{array}{l}\text { Bone } \\
\text { marrow, } \\
\text { blood, lungs }\end{array}$ & $\begin{array}{l}\text { AmB } 0.5 \\
\mathrm{mg} / \mathrm{kg} / \text { day, } \\
\text { itraconazole } 400 \\
\mathrm{mg} / \text { day }\end{array}$ & $\begin{array}{l}\text { + Histopathology } \\
\text { + Blood culture } \\
\text { + Bone marrow } \\
\text { culture } \\
\text { + Urine } \\
\text { Histoplasma Ag }\end{array}$ & $\begin{array}{l}\text { Illinois, } \\
\text { U.S.A. }\end{array}$ & $\begin{array}{l}\text { Tacrolimus 3-5 } \\
\text { mg/day, prednisone } \\
15-20 \text { mg/day }\end{array}$ \\
\hline
\end{tabular}

¥ Authors' affiliated hospital location was used as case geographical location, unless otherwise explicitly noted in case report; *Donor derived infection suspected; † Poster abstract or case/procedure vignette; ๆ Medication names and doses listed as reported in publication; • Patient death reported; \pm Treatment dose and duration included when specified in case report; $₫$ Post-treatment prophylaxis with itraconazole continued indefinitely; $\diamond$ Medication discontinued due to intolerance.

$\mathrm{N} / \mathrm{A}=$ not available; $\operatorname{yr}(\mathrm{s})=$ year(s); mo. = months; $w \mathrm{k}(\mathrm{s})=$ week(s); $\mathrm{mg}=$ milligram; $\mathrm{kg}=$ kilogram; $\mathrm{LAmB}=$ liposomal amphotericin $\mathrm{B} ; \mathrm{AmB}=\mathrm{amphotericin} \mathrm{B} ; \mathrm{ABLC}$ = amphotericin B lipid complex; MMF = mycophenolate mofetil; U.S.A. = United States of America; $\mathrm{PCR}=$ polymerase chain reaction; $\mathrm{BAL}=$ bronchoalveolar lavage; $\mathrm{Gl}=$ gastrointestinal; Antigen = Ag; Antibody $=\mathrm{Ab}$ 


\section{Clinical Features}

Progressive disseminated infection, with evidence of extrapulmonary tissue involvement, is the most common manifestation of Histoplasma infection in transplant recipients [1, 10, 26]. Shallot et al. illustrated this in the first published case of disseminated histoplasmosis after OLT [25]. Regarding presenting signs and symptoms, a wide spectrum has been reported in cases of histoplasmosis in OLT; however, febrile illness was one of the most common among the published cases we reviewed (Table 1; cases $2-4,6-8,13$, and 14). The average time to infection posttransplant is typically within the first two years, but this can vary from a few months to several years [1]. In our review of published case reports, we found that the mean onset of infection occurred at 46.6 months post-liver transplant, with a range of 5 to 180 months (Table 1). With dissemination and progression of histoplasmosis, hepatosplenomegaly, respiratory symptoms, gastrointestinal (GI) tract involvement (e.g. oral ulcers and diarrhea), pancytopenia, anorexia, weight loss, and transaminitis commonly develop. Case 2 highlighted disseminated histoplasmosis with severe, life-threatening symptoms in an OLT recipient. Case 1 illustrated an insidious presentation of presumed histoplasmosis in an OLT recipient, defined by months of intractable diarrhea without other symptoms and focal colonic disease found on colonoscopy. Interestingly, colonic histoplasmosis was first described in 1908 by Samuel T. Darling during a postmortem examination and has since been described in multiple case reports in immunocompromised hosts, including multiple OLT recipients [23]. We identified six case reports with prominent GI symptomatology, and all were subsequently found to have histoplasmosis involvement of the GI tract (Table 1; cases 3, 5, 7, 9, 11, and 13). Less common, but more severe, manifestations of histoplasmosis, such as thrombotic microangiopathy, hemophagocytic lymphohistiocytosis, adrenal insufficiency, osteoarticular, peritoneal, and genitourinary infection, have been described in transplant recipients [1]. Leite et al. presented an abstract of a 15-year-old female with left knee pain who was discovered to have Histoplasma capsulatum in the synovial fluid nine months after OLT (Table 1, case 10) [22]. Although central nervous system (CNS) histoplasmosis has been described in immunocompromised hosts, we did not find any published cases occurring in OLT recipients.

\section{Diagnosis}

A combination of the different diagnostic modalities is often needed to diagnose histoplasmosis. Identification of the tuberculate macroconidia (Figure 1) in culture allows a presumptive diagnosis of histoplasmosis; however, a definitive test to verify the fungus as Histoplasma should always be performed [27]. A commercially available chemiluminescent DNA probe for Histoplasma capsulatum (AccuProbe; GenProbe, Inc., San Diego, CA) is the confirmatory test most often used for definitive diagnosis [27]. In the presence of a compatible clinical presentation, identification of intracellular yeast forms, consistent with Histoplasma, on histopathology is an alternative to culture diagnosis (Figure 2). Grocott's (Gomori's) methenamine silver (GMS) and periodic acid Schiff (PAS) stains are useful in identifying Histoplasma in tissue. Wright-Giemsa stain can help identify intracellular yeast in peripheral blood [28].

Antigen detection in urine and blood is another commonly used method for diagnosis and is particularly helpful, as culture can take up to 3-4 weeks to provide a result. Urine antigen 
detection has been reported to be the most sensitive test in solid organ transplant (SOT) patients (>90\%). In a study on histoplasmosis after SOT, Assi et al. reported that the urine Histoplasma antigen was positive in 132/142 (93\%) patients, including 24 OLT recipients [26]. The sensitivity of Histoplasma urine antigen was $100 \%$ among all SOT recipients tested [12]. In a multicenter study that included immunocompetent and immunocompromised patients, the degree of antigenuria correlated with immune status and the severity of disseminated histoplasmosis [29]. The presence of Histoplasma antigen in samples other than blood and urine can be helpful in establishing a diagnosis. Antigen detection in bronchoalveolar lavage (BAL) fluid, for example, can provide a means of rapid diagnosis of pulmonary histoplasmosis [30]. In cases of CNS histoplasmosis, data from a large, retrospective, multicenter study, which included transplant (13\%) and non-transplant patients, Histoplasma antigen was detected in the cerebrospinal fluid (CSF) in 53 (68.8\%) patients, these patients were more likely to be immunocompromised patients or those with severe disease [31].

The Histoplasma antigen assay is susceptible to cross-reactivity with other organisms and, thus, is not sufficient to diagnose histoplasmosis in the absence of additional supporting diagnostics. This has been described with Blastomyces, Coccidioides, Paracoccidioides, Sporothrix, Aspergillus, and Talaromyces marneffei [27, 29, 32-34]. Similarly, a false-positive Aspergillus antigen test may be seen in patients with histoplasmosis, especially those with high titers. In the presence of a compatible clinical presentation, a positive Aspergillus antigen should foster consideration for Histoplasma antigen testing [35]. False-positive antigenemia has also been described in SOT recipients who receive antithymocyte globulin (ATG) [36]. This is suspected to be due to humananti-rabbit antibodies causing interference with the assay. Similar interferences have been reported in other tests in patients receiving rabbit ATG, and clinicians should be aware of possible false-positive immunoassay results [36]. Specifically, a positive serum Histoplasma antigen with a concurrent negative urine Histoplasma antigen should raise suspicion of a false-positive result [27].

Like in other SOT patients, it is difficult to discern if histoplasmosis in OLT recipients represents a primary infection, reactivation of prior infection, or donor-derived infection. Molecular testing has been utilized in such cases for epidemiological and monitoring purposes. Limaye et al. reported on the use of molecular diagnostic methods to link two cases of disseminated histoplasmosis in renal transplant recipients who received organs from the same donor [16]. The DNA-finger print of the Histoplasma isolate, identified by random amplified polymorphic DNA polymerase chain reaction (RAPD-PCR), was identical between the two recipients, suggesting donor-derived histoplasmosis [16].

Histoplasma antigen works by detecting Histoplasma galactomannan that is present in its cell wall. As an additional component of the cell wall, (1-3)- $\beta$-D-glucan (BG) has had little data on its use as a marker of histoplasmosis infection. A study by Egan et al. comparing BG to Histoplasma antigen tests in patients with presumptive histoplasmosis found positive results in 20/23 (87\%) cases [37]. Due to its presence in the cell wall composition of several fungal pathogens (e.g. Candida sp., Aspergillus sp., and Pneumocystis jirovecii), the specificity of the BG test is low [37].

Modern imaging modalities can provide excellent resolution for visualization of infectious processes, but imaging is usually limited to detecting advanced disease states. There are isolated case reports of diagnosing disseminated histoplasmosis with 18-Fluorodeoxyglucose positron emission tomography $\left({ }^{18} \mathrm{~F}-\mathrm{FDG}-\mathrm{PET} / \mathrm{CT}\right)$ [38-41]. In areas where Histoplasma is endemic, certain 
findings, such as adrenal masses with intense FGD uptake, should raise suspicion for histoplasmosis but does not provide a definitive diagnosis of histoplasmosis [41].

Early diagnosis of histoplasmosis in OLT recipients is key to preserving graft function and achieving good patient outcomes. This is accomplished through providers maintaining a high index of suspicion and providing prompt clinical evaluations at the onset of symptoms. Intervention with multiple diagnostic modalities, including early invasive procedures to obtain material for histopathology and culture, may be required to make a definitive diagnosis.

\section{Treatment}

Treatment of histoplasmosis is driven primarily by the severity and extent of disease. The severity of infection is determined clinically and graded by the need for hospitalization, presence of hemodynamic instability, respiratory status, and extent of infection; which is ranked as mild, moderate, or severe. The most common manifestation of histoplasmosis in OLT recipients, as part of the SOT population, is progressive disseminated disease [1]. The American Society of Transplantation Infectious Diseases Community of Practice (AST IDCOP) guidelines for the treatment of endemic fungal infections in SOT patients recommends itraconazole monotherapy in mild to moderate cases [1]. In moderately-severe to severe infections, initial treatment with amphotericin for one-to-two weeks, followed by step-down therapy with itraconazole is recommended [1]. For disseminated disease, Amphotericin B products are preferred, and the choice of formulation is determined by availability, tolerability, and cost $[1,10]$. Ultimately, the duration of therapy is determined by clinical response and adequate improvement. When possible, immunosuppression should be reduced as it is an essential adjunctive to treatment [1]. In progressive disseminated histoplasmosis, select patients may be placed on indefinite therapy with itraconazole in cases where immunosuppression cannot be reduced [10]. Patients with a history of histoplasmosis within two years preceding transplantation should be considered for itraconazole prophylaxis to prevent infection reactivation [10]. There is limited data available on salvage therapy in those who fail amphotericin B or itraconazole.

Itraconazole levels should be checked after steady-state has been reached, generally two weeks after initiating therapy to identify sufficient levels and to optimize therapy. A random itraconazole blood concentration level that is recommended for adequate therapy is at least 1.0 $\mu \mathrm{g} / \mathrm{ml}$ [10]. The oral solution formulation of itraconazole is absorbed better than the capsule formulation, reaching approximately a 30\% higher blood concentration [10]. Azole blood level monitoring is available through most large reference laboratories [10].

In cases of itraconazole intolerance, serious drug interactions, or inadequate blood levels, newer azoles (e.g. voriconazole, isavuconazole, and posaconazole) have been used as an alternative to first-line therapy but are limited to case reports and small series [1, 12, 42, 43]. Posaconazole and voriconazole have demonstrated in vitro activity against Histoplasma and have been successfully used in a small number of patients with histoplasmosis; however, studies are lacking in transplant recipients [44, 45]. Isavuconazole was used as primary therapy in a study by Thompson et al. with limited success [46]. Fluconazole is the recommended second-line azole for histoplasmosis; however, it is less effective than itraconazole $[10,47,48]$. Lastly, ketoconazole is effective in mild cases of histoplasmosis, but it is not used regularly for histoplasmosis in the U.S. due to an increased number of adverse events [10]. 
Itraconazole is a potent cytochrome P450 3A4 inhibitor. Interactions with calcineurin inhibitors like tacrolimus, sirolimus, and cyclosporine are common, leading to increased serum drug concentrations. Their levels must be monitored closely in OLT recipients with appropriate dose adjustments, particularly at the time of initiation and discontinuation of antifungal therapy [49].

Histoplasma antigen levels typically fall with effective therapy and can be used as a marker of treatment response. Per Infectious Diseases Society of America (IDSA) guidelines, monitoring of serum and urine Histoplasma antigen levels is recommended before treatment initiation and then at two weeks, one month, and every three months thereafter while on therapy $[1,10]$. In case 2 , the patient's urine Histoplasma antigen measurement at diagnosis and at two weeks after starting therapy was $>25.0 \mathrm{ng} / \mathrm{mL}$ (reference range: $<0.5 \mathrm{ng} / \mathrm{mL}$ ); however, after one month of treatment, his urine antigen level decreased to $20 \mathrm{ng} / \mathrm{mL}$. After completion of therapy, Histoplasma antigen monitoring is recommended for 12 months [10]. Levels of serum and urine antigen usually fall to undetectable levels in most patients after the first few months; however, SOT recipients clear antigen levels slowly and can have persistently positive antigen levels after ten months of treatment [1, 42]. Relapse has been documented to occur more often after discontinuation of therapy when urine Histoplasma antigen (MiraVista $\mathrm{Ag}^{\circledR}$ ) levels are $>2 \mathrm{ng} / \mathrm{mL}$ [1]. A rise in antigen levels during monitoring should prompt consideration for histoplasmosis relapse and reinitiating treatment.

\section{Outcomes, Screening, and Prophylaxis}

Treatment of moderate-to-severe histoplasmosis in SOT recipients with amphotericin followed by prolonged itraconazole is highly effective, with most case series in the SOT population reporting treatment efficacy from $80 \%-100 \%[1,12,42,47]$. Mortality rates in three series that included SOT recipients with histoplasmosis were between $15 \%-27 \%$ with attributable rates of $10 \%, 9 \%$ (2 cases), 10.4\% (5 cases), respectively [15, 26, 42]. Most deaths occurred within a month of diagnosis. Rarely, IRIS has been described in SOT patients with disseminated histoplasmosis, often in the setting of concomitant immunosuppression reduction [1]. Jazwinski et al. reported a case of IRIS occurring in a SOT patient with severe disseminated histoplasmosis [50]. Management is predominately supportive but can include corticosteroids to dampen the inflammatory reaction in severe cases. Currently, the use of primary prophylaxis in transplant patients is not recommended; however, secondary prophylaxis with itraconazole can be considered in patients with previously reported histoplasmosis within two years before transplantation [1]. In some select cases, OLT patients may receive secondary prophylaxis with itraconazole to prevent-donor histoplasmosis (Table 1, case 7). The optimal duration of secondary prophylaxis is not known. Pretransplant serological screening in endemic areas for prior Histoplasma exposure is not recommended due to poor predictive value $[1,51]$. This recommendation was based on a study in SOT recipients done by Vail et al., as serologic signs of previous infection and imaging findings did not appear to increase the risk of developing infection [51]. There are currently no recommendations to screen donors for histoplasmosis.

\section{Discussion}

We present two cases of unique presentations of Histoplasma infection in OLT recipients and add to the limited published data (Table 1). Case 1 described a subtle presentation of presumed 
gastrointestinal histoplasmosis occurring 12 years after OLT. The differential diagnosis for this case included malignancy, autoimmune disease, MMF-related colitis, cytomegalovirus infection, or other bacterial causes of colitis. A presumed diagnosis of Histoplasma capsulatum was ultimately made by broad range PCR performed on colonic tissue. Due to difficulties tolerating itraconazole, treatment consisted of two weeks of liposomal amphotericin B with resolution of the patient's diarrhea and colonic ulcers.

Case 2 illustrated severe pulmonary histoplasmosis with dissemination in an OLT recipient one year after transplantation, presenting as weeks of fever and cough. The differential diagnosis for this case included respiratory viruses, pneumocystis pneumonia, bacterial pneumonia, invasive fungal pneumonias with aspergillosis, and coccidioidomycosis. The diagnosis was made through observation of intracellular yeast forms on BAL and culture that grew Histoplasma capsulatum, which was confirmed by DNA probe. Treatment was complicated by the development of refractory shock and ARDS, requiring adjunctive corticosteroids.

In summarizing a review of the literature on histoplasmosis in OLT recipients, we focused on the following areas: epidemiology, clinical manifestations, diagnosis, treatment, and prevention. The primary weakness of our review was a lack of available large case series focusing on histoplasmosis, specifically in OLT patients, as many of the larger case series included a blended SOT population. Because of this, there remain several unanswered questions regarding optimal diagnosis and treatment of histoplasmosis in OLT recipients. New advances in fungal diagnostics are allowing for more precise and rapid diagnosis of histoplasmosis, but their availability and validation in the transplant population are not yet standardized. The rarity of histoplasmosis in OLT recipients has limited attempts at performing randomized controlled trials to provide evidence-based recommendations on treatment. At this time, azoles and amphotericin B remain the only antifungals available for the treatment of histoplasmosis. The newer azoles are available for treatment and prophylaxis, but further studies are needed to validate their use in OLT recipients. As in other fungal infections, the development of new antifungal drug classes for histoplasmosis is needed to provide additional treatment options in cases of intolerance, treatment failure, and severe drug interactions. Lastly, additional studies to provide better understanding of the role of the host immune system, iatrogenic immunosuppression, immune modulation, by histoplasmosis, and immune clearance of infection are needed to advance our knowledge and possibly provide immunotherapeutic treatment options. With an ever-increasing transplant patient population and an expanding endemic region, more Histoplasma infections are likely to occur in both donors and OLT recipients, necessitating the need for further studies in each of the fields discussed above.

\section{Acknowledgments}

We thank Dr. Todd M. Lasco for laboratory support and providing images for this report, and we thank Liaison Librarian Amy Sisson for her assistance with a literature search at The Texas Medical Center Library, Houston, TX 77030, USA.

\section{Author Contributions}

All authors contributed to this manuscript equally. 


\section{Funding}

This project did not use funding support.

\section{Competing Interests}

The authors have declared that no competing interests exist.

\section{References}

1. Miller R, Assi M. Endemic fungal infections in solid organ transplant recipients-Guidelines from the American Society of Transplantation Infectious Diseases Community of Practice. Clin Transplant. 2019; 33: e13553.

2. Botterel F, Romand S, Saliba F, Reynes M, Bismuth H, Samuel D, et al. A case of disseminated histoplasmosis likely due to infection from a liver allograft. Eur J Clin Microbiol Infect Dis. 1999; 18: 662-664.

3. Nakamura GP, Moraes RM, Siqueira JM, de Oliveira ACF, Begnami M, Jaguar GC. Oral ulcerative lesions in a post-liver-transplantation patient. Autops Case Rep. 2019; 9: e2018046.

4. Agrawal N, Jones DE, Dyson JK, Hoare T, Melmore SA, Needham S, et al. Fatal gastrointestinal histoplasmosis 15 years after orthotopic liver transplantation. World J Gastroenterol. 2017; 23: 7807-7812.

5. Gajurel K, Dhakal R, Deresinski S. Histoplasmosis in transplant recipients. Clin Transplant. 2017; 31.

6. Bahr NC, Antinori S, Wheat LJ, Sarosi GA. Histoplasmosis infections worldwide: Thinking outside of the Ohio River valley. Curr Trop Med Rep. 2015; 2: 70-80.

7. Antinori S. Histoplasma capsulatum: More widespread than previously thought. Am J Trop Med Hyg. 2014; 90: 982-983.

8. Maiga AW, Deppen S, Scaffidi BK, Baddley J, Aldrich MC, Dittus RS, et al. Mapping Histoplasma capsulatum Exposure, United States. Emerg Infect Dis. 2018; 24: 1835-1839.

9. Kauffman CA, Miceli MH. Histoplasmosis and blastomycosis in solid organ transplant recipients. J Fungi (Basel). 2015; 1: 94-106.

10. Wheat LJ, Freifeld AG, Kleiman MB, Baddley JW, McKinsey DS, Loyd JE, et al. Clinical practice guidelines for the management of patients with histoplasmosis: 2007 update by the Infectious Diseases Society of America. Clin Infect Dis. 2007; 45: 807-825.

11. Batista MV, Pierrotti LC, Abdala E, Clemente WT, Girão ES, Rosa DRT, et al. Endemic and opportunistic infections in Brazilian solid organ transplant recipients. Trop Med Int Health. 2011; 16: 1134-1142.

12. Freifeld AG, Iwen PC, Lesiak BL, Gilroy RK, Stevens RB, Kalil AC. Histoplasmosis in solid organ transplant recipients at a large Midwestern university transplant center. Transpl Infect Dis. 2005; 7: 109-115.

13. Singh N, Huprikar S, Burdette SD, Morris MI, Blair JE, Wheat LJ. Donor-derived fungal infections in organ transplant recipients: Guidelines of the American Society of Transplantation, infectious diseases community of practice. Am J Transplant. 2012; 12: 24142428. 
14. Sylvestre PB, Gonzalez-Koch AR, Ishitani MB. Histoplasmosis in an explant liver with subsequent seeding of the liver allograft. Liver Transpl. 2000; 6: 643.

15. Kauffman CA, Freifeld AG, Andes DR, Baddley JW, Herwaldt L, Walker RC, et al. Endemic fungal infections in solid organ and hematopoietic cell transplant recipients enrolled in the Transplant-Associated Infection Surveillance Network (TRANSNET). Transpl Infect Dis. 2014; 16: 213-224.

16. Limaye AP, Connolly PA, Sagar M, Fritsche TR, Cookson BT, Wheat LJ, et al. Transmission of Histoplasma capsulatum by organ transplantation. N Engl J Med. 2000; 343: 1163-1166.

17. Niyazi F, Saeed A, Tosch K, Mullins K, Jafri S-M. Symptomatic disseminated histoplasmosis acquired by liver transplantation: 803. Am J Gastroenterol. 2015; 110: S351.

18. Gomez-Santana LV, Torre AC, Hernandez BA, Volonteri VI, Laura B, Luis-Galimberti R. Mucocutaneous manifestations of infection by Histoplasma capsulatum in HIV-negative immunosuppressed patients. Actas Dermosifiliogr. 2018; 109: e27-e32.

19. Washburn L, Galvan NT, Dhingra S, Rana A, Goss JA. Histoplasmosis hepatitis after orthotopic liver transplantation. J Surg Case Rep. 2017; 2017: rjx232.

20. Wiederkehr J, Nogara M, Igreja M, Godoy M, Drago C, Goncalves N, et al. Inferior vena cava syndrome secondary to disseminated Histoplasmosis - a diagnostic challenge.: Abstract\# D2428. Transplantation. 2014; 98: 261.

21. Colaiacovo R, de Castro AC, Shiang C, Ganc RL, Ferrari AP, Jr. Disseminated histoplasmosis: A rare cause of multiple ulcers in the gastrointestinal tract. Endoscopy. 2011; 43: E216.

22. Leite CAC, Souza IJN, Leite RD, Garcia JHP, C. RFA. Histoplasma capsulatum arthritis of the knee after liver transplantation in adolescent: Case report. Liver Transpl. 2009; 15: S10-S299.

23. Oh YS, Lisker-Melman M, Korenblat KM, Zuckerman GR, Crippin JS. Disseminated histoplasmosis in a liver transplant recipient. Liver Transpl. 2006; 12: 677-681.

24. Vinayek R, Balan V, Pinna A, Linden PK, Kusne S. Disseminated histoplasmosis in a patient after orthotopic liver transplantation. Clin Transplant. 1998; 12: 274-277.

25. Shallot J, Pursell KJ, Bartolone C, Williamson P, Benedetti E, Layden TJ, et al. Disseminated histoplasmosis after orthotopic liver transplantation. Liver Transpl Surg. 1997; 3: 433-434.

26. Assi M, Martin S, Wheat $\amalg$, Hage $C$, Freifeld A, Avery R, et al. Histoplasmosis after solid organ transplant. Transpl Infect Dis. 2013; 57: 1542-1549.

27. Kauffman CA. Histoplasmosis: A clinical and laboratory update. Clin Microbiol Rev. 2007; 20: 115-132.

28. Azar MM, Hage CA. Laboratory diagnostics for histoplasmosis. J Clin Microbiol. 2017; 55: 1612-1620.

29. Hage CA, Ribes JA, Wengenack NL, Baddour LM, Assi M, McKinsey DS, et al. A multicenter evaluation of tests for diagnosis of histoplasmosis. Transpl Infect Dis. 2011; 53: 448-454.

30. Hage CA, Davis TE, Egan L, Parker M, Fuller D, Lemonte AM, et al. Diagnosis of pulmonary histoplasmosis and blastomycosis by detection of antigen in bronchoalveolar lavage fluid using an improved second-generation enzyme-linked immunoassay. Respir Med. 2007; 101: 43-47.

31. Wheat J, Myint T, Guo Y, Kemmer P, Hage C, Terry C, et al. Central nervous system histoplasmosis: Multicenter retrospective study on clinical features, diagnostic approach and outcome of treatment. Medicine. 2018; 97: e0245. 
32. Hage CA, Davis TE, Fuller D, Egan L, Witt JR, 3rd, Wheat $L$, et al. Diagnosis of histoplasmosis by antigen detection in BAL fluid. Chest. 2010; 137: 623-628.

33. Connolly PA, Durkin MM, Lemonte AM, Hackett EJ, Wheat LJ. Detection of histoplasma antigen by a quantitative enzyme immunoassay. Clin Vaccine Immunol. 2007; 14: 1587-1591.

34. Assi M, Lakkis IE, Wheat $L$. Cross-reactivity in the Histoplasma antigen enzyme immunoassay caused by sporotrichosis. Clin Vaccine Immunol. 2011; 18: 1781-1782.

35. Vergidis P, Walker RC, Kaul DR, Kauffman CA, Freifeld AG, Slagle DC, et al. False-positive Aspergillus galactomannan assay in solid organ transplant recipients with histoplasmosis. Transpl Infect Dis. 2012; 14: 213-217.

36. Wheat $\amalg$, Connolly P, Durkin M, Book BK, Tector AJ, Fridell J, et al. False-positive Histoplasma antigenemia caused by antithymocyte globulin antibodies. Transpl Infect Dis. 2004; 6: 23-27.

37. Egan L, Connolly P, Wheat LJ, Fuller D, Dais TE, Knox KS, et al. Histoplasmosis as a cause for a positive Fungitell (1 --> 3)-beta-D-glucan test. Med Mycol. 2008; 46: 93-95.

38. Kasaliwal R, Malhotra G, Bukan A, Asopa RV, Wanjare S, Shah NS. 18F-FDG PET as a monitoring tool to assess treatment response in bilateral adrenal histoplasmosis. Clin Nucl Med. 2014; 39: 576-578.

39. Muller N, Kessler R, Caillard S, Epailly E, Hubele F, Heimburger C, et al. ${ }^{18}$ F-FDG PET/CT for the diagnosis of malignant and infectious complications after solid organ transplantation. Nucl Med Mol Imaging. 2017; 51: 58-68.

40. Sahoo MK, Tripathi M, Deepak R, Gupta RK, Damle N, Bal C. Disseminated histoplasmosis demonstrated on F18-fluorodeoxyglucose positron emission tomography/computed tomography in a renal transplant recipient. Indian J Nucl Med. 2016; 31: 162-164.

41. Sharma P, Mukherjee A, Karunanithi S, Bal C, Kumar R. Potential role of 18F-FDG PET/CT in patients with fungal infections. AJR Am J Roentgenol. 2014; 203: 180-189.

42. Grim SA, Proia L, Miller R, Alhyraba M, Costas-Chavarri A, Oberholzer J, et al. A multicenter study of histoplasmosis and blastomycosis after solid organ transplantation. Transpl Infect Dis. 2012; 14: 17-23.

43. Freifeld A, Proia L, Andes D, Baddour LM, Blair J, Spellberg B, et al. Voriconazole use for endemic fungal infections. Antimicrob Agents Chemother. 2009; 53: 1648-1451.

44. Restrepo A, Tobon A, Clark B, Graham DR, Corcoran G, Bradsher RW, et al. Salvage treatment of histoplasmosis with posaconazole. J Infect. 2007; 54: 319-327.

45. Clark B, Foster R, Tunbridge A, Green S. A case of disseminated histoplasmosis successfully treated with the investigational drug posaconazole. J Infect. 2005; 51: e177-e180.

46. Thompson GR, 3rd, Rendon A, Ribeiro Dos Santos R, Queiroz-Telles F, Ostrosky-Zeichner L, Azie $\mathrm{N}$, et al. Isavuconazole treatment of cryptococcosis and dimorphic mycoses. Clin Infect Dis. 2016; 63: 356-362.

47. Cuellar-Rodriguez J, Avery RK, Lard M, Budev M, Gordon SM, Shrestha NK, et al. Histoplasmosis in solid organ transplant recipients: 10 years of experience at a large transplant center in an endemic area. Clin Infect Dis. 2009; 49: 710-716.

48. McKinsey DS, Kauffman CA, Pappas PG, Cloud GA, Girard WM, Sharkey PK, et al. Fluconazole therapy for histoplasmosis. The National Institute of Allergy and Infectious Diseases Mycoses Study Group. Clin Infect Dis. 1996; 23: 996-1001. 
49. Lempers VJ, Martial LC, Schreuder MF, Blijlevens NM, Burger DM, Aarnoutse RE, et al. Druginteractions of azole antifungals with selected immunosuppressants in transplant patients: Strategies for optimal management in clinical practice. Curr Opin Pharmacol. 2015; 24: 38-44.

50. Jazwinski A, Naggie S, Perfect J. Immune reconstitution syndrome in a patient with disseminated histoplasmosis and steroid taper: Maintaining the perfect balance. Mycoses. 2011; 54: 270-272.

51. Vail GM, Young RS, Wheat $\amalg$, Filo RS, Cornetta K, Goldman M. Incidence of histoplasmosis following allogeneic bone marrow transplant or solid organ transplant in a hyperendemic area. Clin Infect Dis. 2002; 4: 148-151.

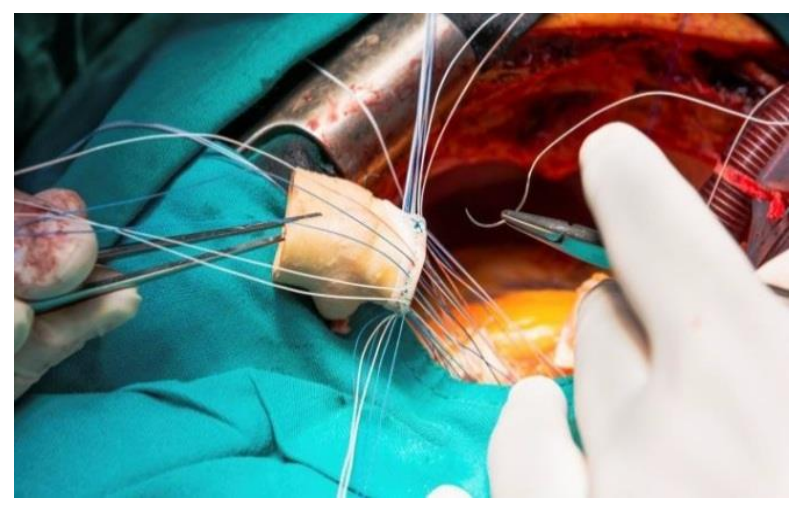

Enjoy OBM Transplantation by:

1. Submitting a manuscript

2. Joining in volunteer reviewer bank

3. Joining Editorial Board

4. Guest editing a special issue

For more details, please visit:

http://www.lidsen.com/journals/transplantation 